JURNAL KEBIDANAN

Vol 6, No 2, April 2020 : 244-248

\title{
PENGARUH PEMBERIAN TELUR REBUS DENGAN PERCEPATAN PENYEMBUHAN LUKA PERINEUM
}

\author{
Venti Williani Santika ${ }^{1}$, Neneng Siti Lathifah², Febriyantina Parina ${ }^{3}$ \\ 1Program Studi DIV Kebidanan Fakultas Kedokteran Universitas Malahayati Bandar Lampung \\ Korespondensi Email : ventiws@gmail.com \\ 2Dosen DIV Kebidanan Universitas Malahayati \\ Email : nenengmalahayati@gmail.com \\ ${ }_{3}^{3}$ Pegawai Dinas Kota Bandar Lampung \\ Email: febri@gmail.com
}

\begin{abstract}
Background As a result of perineal rupture in mothers, $10 \%$ of mothers experience pain that ends after 3-18 months of labor, as many as 20\% of mothers experience pain when coitus is around 3 months, $3-10 \%$ of mothers report intestinal incontinence, 20\% experience urinary incontinence, damage A faint anal sphincter occurs in $36 \%$ although third and fourth degree tears are repaired. One solution for post partum mothers is the idea obtained from the world, which is animal food, boiled eggs

The purpose of the study is known the effect of boiled egg administration with the acceleration of perineal wound healing at BPS Nurhasanah, STr., Keb Gudang Auction, Bandar Lampung City in 2019.

Methods Quantitative research type, Experimental Quasy research design with two group pretestposttest. The population of post partum mothers 1-7 days was 50 people, samples of post partum mothers with perineal suture injuries were 40 people, purposive sampling technique aside, respondents were divided into 2 groups: the intervention group were 20 people given boiled eggs 3 times a day for 7 days, the control group that is not given boiled eggs. measuring instruments used observation sheets. data analysis using univariate to determine the frequency distribution, average injuries before and after bivariate and intervensid analysis, with $t$ independent statistical tests

Results The average perineal wound before being given intervention in the consumption of boiled chicken eggs in BPS Nurhasanah, Str., Keb Lampung Auction Warehouse in Bandar Lampung City in 2019 with Mean 6.85 Min 3 Max 9 and Standard Deviation 1.694, after being given the intervention of boiled chicken egg consumption in BPS Nurhasanah, Str., Keb Lampung Auction Warehouse in Bandar Lampung City in 2019 with Mean 2.35 Min 1 Max 4 and Standard Deviation 0.813. Statistical test results obtained a value of $P$-value $=0.003$ $(<0.05)$, which means that there is an effect of boiled egg administration with the acceleration of perineal wound healing at BPS Nurhasanah, Str., Keb Gudang Auction in Bandar Lampung City in 2019.

The conclusion is the effect of boiled egg administration with the acceleration of perineal wound healing at BPS Nurhasanah, Str., Keb Gudang Auction City of Bandar Lampung in 2019.

Suggestions It is expected that the results of this study can be used as input for clients and BPS who are around in order to accelerate perineal injury by means of post partum mothers consuming boiled eggs
\end{abstract}

Keywords: Wound Healing, Perineum, Boiled Eggs

\section{ABSTRAK}

Latar Belakang Akibat rupture perineum pada ibu yaitu 10\% ibu merasakan nyeri yang berakhir setelah 3-18 bulan persalinan, sebanyak 20\% ibu mengalami nyeri saat coitus sekitar 3 bulan, 3-10\% ibu melaporkan inkontinensia usus, $20 \%$ mengalami inkontinensia urine, kerusakan sfingter anal samar terjadi pada $36 \%$ walaupun robekan derajat tiga dan empat diperbaiki. Salah satu solusi bagi ibu post partum adalah gagasan yang diperoleh dari dunia yaitu makanan hewani yaitu telur rebus

Tujuan penelitian diketahui pengaruh pemberian telur rebus dengan percepatan penyembuhan luka perineum di BPS Nurhasanah, STr., Keb Gudang Lelang Kota Bandar Lampung tahun 2019.

Metode Jenis penelitian kuantitatif, Rancangan penelitian Quasy Eksperimental dengan two group pretes-postes. Populasi ibu post partum hari ke 1-7 sebanyak 50 orang, sampel ibu post partum dengan luka jahitan perineum sebanyak 40 orang, teknik sampling purposive samping, Responden dibagi 2 kelompok yaitu kelompok intervensi sebanyak 20 orang diberikan telur rebus sehari 3 kali selama 7 hari, kelompok yang control 
yaitu yang tidak diberikan telur rebus. alat ukur yang digunakan lembar observasi .analisa data menggunakan univariat untuk mengetahui distribusi frekuensi, rata-rata luka sebelum dan sesudah dilakukan intervensid an bivariate, dengan uji statistik t-independent

Hasil Rata-rata luka perineum sebelum diberi intervensi konsumsi telur ayam rebus di BPS Nurhasanah, Str., Keb Gudang Lelang Kota Bandar Lampung Tahun 2019 dengan Mean 6,85 Min 3 Max 9 dan Standar Deviasi 1,694, sesudah diberi intervensi konsumsi telur ayam rebus di BPS Nurhasanah, Str., Keb Gudang Lelang Kota Bandar Lampung Tahun 2019 dengan Mean 2,35 Min 1 Max 4 dan Standar Deviasi 0,813. Hasil uji statistik didapatkan nilai $P$-value $=0.003(<0,05)$ yang artinya terdapat pengaruh pemberian telur rebus dengan percepatan penyembuhan luka perineum di BPS Nurhasanah, Str., Keb Gudang Lelang Kota Bandar Lampung Tahun 2019.

Kesimpulan ada pengaruh pemberian telur rebus dengan percepatan penyembuhan luka perineum di BPS Nurhasanah, Str., Keb Gudang Lelang Kota Bandar Lampung Tahun 2019.

Saran Diharapkan hasil penelitian ini dapat digunakan sebagai masukan bagi klien dan BPS yang berada disekitar agar dapat mempercepat luka perineum dengan cara ibu post partum mengkonsumsi telur rebus

Kata Kunci : Penyembuhan Luka, Perineum, Telur Rebus

\section{PENDAHULUAN}

Persalinan adalah proses pengeluaran hasil konsepsi yang dapat hidup dari dalam uterus melalui vagina ke dunia luar. (Prawirohardjo, 2016). Luka perineum adalah luka perineum karena adanya robekan jalan lahir baik karena rupture maupun karena episiotomy pada waktu melahirkanjanin. Rupture perineum adalah robekan yang terjadi pada perineum sewaktu persalinan. Robekan jalan lahir merupakan luka atau robekan jaringan yang tidak teratur (Walyani, 2015). Oleh karena itu bentuk laserasi perineum dibedakan menjadi 2 yaitu bentuk laserasi perineum ruptur dan episiotomi.Sekitar $85 \%$ wanita yang melahirkan spontan pervaginam mengalami trauma perineum berupa $32-33 \%$ karena tindakan episiotomi dan $52 \%$ merupakan laserasi spontan.

Salah satu solusi bagi ibu post partum adalah gagasan yang diperoleh dari dunia yaitu makanan hewani yaitu telur rebus, telur merupakan jenis lauk pauk protein hewani yang murah, mudah ditemukan, ekonomis dan salah satu makanan paling padat nutrisi. Kandungan nutrisi telur rebus utuh mengandung lebih dari $90 \%$ kalsium zat besi, satu telur mengandung 6 gram protein berkualitas dan asam amino esensial. Pada kajian ini telur rebus dan dibuktikan untuk penyembuhan luka jahitan perineum pada ibu pasca persalinan atau ibu post partem karena percepatan penyembuhan luka perineum dalam masa nifas sangat diharapkan untuk menghindari ibu nifas dari bahaya infeksi. Sejumlah hasil penelitian telah membuktikan manfaat telur rebus dibutuhkan untuk kesembuhan luka jahitan perineum pada ibu nifas, mayoritas responden sembuh normal dengan waktu yang dibutuhkan antara 6-7 hari, lamanya waktu yang dibutuhkan untuk kesembuhan jahitan luka perineum terlihat nyata, waktu kesembuhan yang dibutuhkan ibu nifas yang tidak mengkonsumsi telur rebus rata-rata 7,4 hari.

Persalinan di BPS Nurhasanah STr., Keb Gudang Lelang Kota Bandar Lampung, dengan jumlah persalinan selama Januari-Desember tahun 2018 yaitu sebanyak 438 orang, dengan kejadian rupture perineum sebanyak 95 orang yang diakibatkan oleh rupture spontan.Berdasarkan prasurvey yang dilakukan di BPS Nurhasanah Gudang Lelang Kota Bandar Lampung diketahui jika BPS tersebut memberikan masukan kepada ibu yang bersalin, namun pada kenyataan yang ada ibu bersalin dengan luka perineum jarang mengkonsumsi telur ataupun ikan, karena mengikuti budaya dari keluarga.Sehingga berdasarkan fenomena diatas peneliti tertarik melakukan penelitian dengan judul "pengaruh pemberian telur rebus dengan percepatan penyembuhan luka perineum di BPS Nurhasanah, STr., Keb Gudang Lelang Kota Bandar Lampung tahun 2019"

\section{METODELOGI PENELITIAN}

Jenis penelitian kuantitatif, Rancangan penelitian Quasy Eksperimental dengan two group pretes-postes. Populasi ibu post partum hari ke 1-7 sebanyak 50 orang, sampel ibu post partum dengan luka jahitan perineum sebanyak 40 orang, teknik sampling purposive samping, Responden dibagi 2 kelompok yaitu kelompok intervensi sebanyak 20 orang diberikan telur rebus sehari 3 kali selama 7 hari, kelompok yang control yaitu yang tidak diberikan telur rebus. alat ukur yang digunakan lembar observasi .analisa data menggunakan univariat untuk mengetahui distribusi 
frekuensi, rata-rata luka sebelum dan sesudah dilakukan intervensid an bivariate, dengan uji statistik t-independent(Notoatmojo,2012)

HASIL PENELITIAN DAN PEMBAHASAN Analisa Univariat

Luka Sebelum Konsumsi Telur
Dari tabel 1 diatas dapat diketahui bahwa rata-rata luka perineum sebelum diberi intervensi konsumsi telur ayam rebus di BPS Nurhasanah, Str., Keb Gudang Lelang Kota Bandar Lampung Tahun 2019 dengan Mean 6,85 Min 3 Max 9 dan Standar Deviasi 1,694.

Tabel 1.

Rata-Rata Luka Perineum Pada kelompok eksperiment Sebelum Diberi Intervensi Konsumsi Telur Ayam Rebus Di BPS Nurhasanah, Str., Keb Gudang Lelang Kota Bandar Lampung Tahun 2019

\begin{tabular}{lccccc}
\hline \multicolumn{1}{c}{ Variabel } & N & Mean & Min-Max & Std. Dev & Cl-95\% \\
\hline $\begin{array}{l}\text { Penyembuhan Luka sebelum } \\
\text { diberi telur rebus }\end{array}$ & 20 & 6,85 & \multirow{2}{*}{$3-9$} & \multirow{2}{*}{1,694} & $\begin{array}{l}-1,543 \\
-0,257\end{array}$ \\
\hline
\end{tabular}

Tabel 2.

Rata-Rata Luka Perineum Pada Kelompok Kontrol Di BPS Nurhasanah, Str., Keb Gudang Lelang Kota Bandar Lampung Tahun 2019

\begin{tabular}{cccccc}
\hline Variabel & N & Mean & Min-Max & Std. Dev & Cl-95\% \\
\hline Luka perineum hari ke 1 & 20 & \multirow{2}{*}{7,40} & \multirow{2}{*}{$3-9$} & \multirow{2}{*}{1,698} & $\begin{array}{c}-1,545 \\
-0,255\end{array}$ \\
\hline
\end{tabular}

Dari tabel 2 diatas dapat diketahui bahwa rata-rata luka perineum pada kelompok kontrol di BPS Nurhasanah, Str., Keb Gudang Lelang Kota Bandar Lampung Tahun 2019 dengan Mean 7,40 Min 3 Max 9 dan Standar Deviasi 1,698.

Luka Setelah Konsumsi Telur

Dari tabel 3. diatas dapat diketahui bahwa rata-rata luka perineum sesudah diberi intervensi konsumsi telur ayam rebus di BPS Nurhasanah, Str., Keb Gudang Lelang Kota Bandar Lampung Tahun 2019 dengan Mean 2,35 Min 1 Max 4 dan Standar Deviasi 0,813

Tabel 3.

Rata-Rata Luka Perineum Sesudah Intervensi Konsumsi Telur Ayam Rebus Di BPS Nurhasanah, Str., Keb Gudang Lelang Kota Bandar Lampung Tahun 2019

\begin{tabular}{lccccc}
\hline \multicolumn{1}{c}{ Variabel } & N & Mean & Min-Max & Std. Dev & Cl-95\% \\
\hline $\begin{array}{l}\text { Penyembuhan Luka sesudah } \\
\text { diberi telur rebus }\end{array}$ & 20 & 2,35 & $1-4$ & 0,813 & $\begin{array}{l}-1,543 \\
-0,257\end{array}$ \\
\hline
\end{tabular}

Tabel 4.

Rata-Rata Luka Perineum Setelah 1 Minggu Pada Kelompok Kontrol Di BPS Nurhasanah, Str., Keb Gudang Lelang Kota Bandar Lampung Tahun 2019

\begin{tabular}{cccccc}
\hline Variabel & N & Mean & Min-Max & Std. Dev & Cl-95\% \\
\hline Luka perineum hari ke 7 & 20 & \multirow{2}{*}{3,25} & \multirow{2}{*}{$1-5$} & \multirow{2}{*}{1,164} & $\begin{array}{c}-1,545 \\
\text { - } 25,255\end{array}$ \\
\hline
\end{tabular}

Dari tabel 4. diatas dapat diketahui bahwa rata-rata luka perineum setelah 1 minggu pada kelompok kontrol di BPS Nurhasanah, Str., Keb Gudang Lelang Kota Bandar Lampung Tahun 2019 dengan Mean 3,25 Min 1 Max 5 dan Standar Deviasi 1,164 . 


\section{Analisa Bivariat}

Dari tabel 5 terlihat bahwa rata-rata percepatan penyembuhan luka perineum di BPS Nurhasanah, Str., Keb Gudang Lelang Kota Bandar Lampung Tahun 2019 pada kelompok pemberian telur rebus dengan Mean 2,35 Standar Deviasi 0,813 dan Standar Eror 0,182, dan pada kelompok

kontrol Mean 3,25 Standar Deviasi 1,164 dan Standar Eror 0,260.

Hasil uji statistik didapatkan nilai $P$-value= $0.007(<0,05)$ yang artinya terdapat pengaruh pemberian telur rebus dengan percepatan penyembuhan luka perineum di BPS Nurhasanah, Str., Keb Gudang Lelang Kota Bandar Lampung Tahun 2019.

Tabel 5.

Pengaruh Pemberian Telur Rebus Dengan Percepatan Penyembuhan Luka Perineum Di BPS Nurhasanah, Str., Keb Gudang Lelang Kota Bandar Lampung Tahun 2019

\begin{tabular}{lcccccc}
\hline \multicolumn{1}{c}{ Variabel } & N & Mean & Std. Dev & SE & P -Value & Cl-95\% \\
\hline Postest (Telur Rebus) & 20 & 2,35 & 0,813 & 0,182 & \multirow{2}{*}{0,007} & $-1,543$ \\
Posttest(Kontrol) & 20 & 3,25 & 1,164 & 0,260 & & $-0,257$ \\
\hline
\end{tabular}

\section{PEMBAHASAN}

Sejalan dengan teori Walyani (2015) Perineum adalah jaringan antara vestibulum vulva dan anus dan panjang kira-kira $4 \mathrm{~cm}$. Luka perineum adalah luka perineum karena adanya robekan jalan lahir baik karena rupture maupun karena episiotomy pada waktu melahirkan janin. Rupture perineum adalah robekan yang terjadi pada perineum sewaktu persalinan. Robekan jalan lahir merupakan luka atau robekan jaringan yang tidak teratur. Pada hasil penelitian ini, rata-rata luka pada ibu bersalin adalah derajat II dengan kriteria skala REEDA berada pada skor 8 hingga 10 maka perlu diberikan intervensi untuk mempercepat penyembuhan luka, seperti memberikan obat dan konsumsi makanan yang banyak mengandung protein.

Sejalan dengan teori Sujiyanti (2010) Faktor gizi terutama protein akan sangat mempengaruhi terhadap proses penyembuhan luka pada perineum karena pergantian jaringan sangat membutuhkan protein. Berdasarkan sumbernya protein dapat dibagi menjadi dua yaitu protein nabati (kedelai, kacang-kacangan, tahu dan tempe) dan protein hewani (ikan, telur, daging sapi, daging ayam, dan susu). Telur mengandung zat-zat makanan yang penting bagi tubuh yakni sumber protein, lemak, vitamin dan mineral yang cukup lengkap, sehingga bisa membantu memperlancar proses-proses metabolisme dalam tubuh.

Menurut peneliti perbaikan gizi merupakan salah satu kunci dari penyembuhan luka. Ibu nifas dianjurkan makan dengan diit seimbang, cukup karbohidrat, protein, lemak, vitamin dan mineral. Faktor gizi utama protein akan sangat berpengaruh terhadap proses penyembuhan luka perineum karena pergantian jaringan sangat membutuhkan protein yang berfungsi sebagai zat pembangun sel- sel yang telah rusak. Peningkatan kebutuhan protein diperlukan untuk proses inflamasi, imun dan perkembangan jaringan granulasi. Menurut peneliti kandungan protein pada telur yang cukup besar dapat membantu proses regenasi kulit, dan penyembuhan melalui percepatan granulasi kulit yang terluka setelah bersalin, pada kelompok intervensi dengan pemberian telur penyembuhan luka dengan baik dengan skor 1-2 sehingga dapat disimpulkan pemberian intervensi telur sangat efektif untuk mempercepat penyembuhan luka, hanya saja akan lebih baik lagi jika diberikan dalam jangka waktu yang lama.

\section{KESIMPULAN}

Distribusi frekuensi rata-rata luka perineum sebelum diberi intervensi konsumsi telur ayam rebus di BPS Nurhasanah, Str., Keb Gudang Lelang Kota Bandar Lampung Tahun 2019 dengan Mean 6,85 Min 3 Max 9 dan Standar Deviasi 1,694. Dan distribusi frekuensi rata-rata luka perineum sesudah diberi intervensi konsumsi telur ayam rebus di BPS Nurhasanah, Str., Keb Gudang Lelang Kota Bandar Lampung Tahun 2019 dengan Mean 2,35 Min 1 Max 4 dan Standar Deviasi 0,813.Dari Hasil uji statistik didapatkan nilai $P$-value $=0.007 \quad(<0,05)$ yang artinya terdapat pengaruh pemberian telur rebus dengan percepatan penyembuhan luka perineum di BPS Nurhasanah, Str., Keb Gudang Lelang Kota Bandar Lampung Tahun 2019

\section{SARAN}

Hasil Peneltian menjadi salah satu alternatif pengobatan pada ibu post partum dalam penyembuhan luka perineum dengan mengkonsumsi telur rebus sehari 3 kali selama 7 hari. 


\section{DAFTAR PUSTAKA}

Astutik, Reni, Yuli. (2015). Asuhan Kebidanan Masa Nifas Dan Menyusui. Jakarta: Trasn Info Media.

Herawati, Puspitarini, 2010. Hubungan Perawatan Perineum Dengan Kesembuhan Luka Perineum Pada Ibu Nifas Hari Keenam Di Bidan Praktik Swasta (Bps) Ny. Sri Suhersi Mojokerto Kedawung Sragen. Surakarta: Universitas Sebelas Maret.

Kristiyanti dkk. (2012). Waktu Penyembuhan Luka Perinemu Dengan Episiotomi Dan Robekan Spontan. Stikes Muhammadiyah Pakenjangan: Pekalongan.

Lamid, Astuti, 2015. Pengaruh Proses Pemasakan Terhadap Komposisi Zat Gizi Bahan Pangan Sumber Protein. Pusat Biomedis dan Teknologi Dasar Kesehatan, Kemenkes RI, Jl. Percetakan Negara No. 29, Jakarta Pusat 10560 ,Indonesia.

Maryunani, Anik 2010. Nyeri Dalam Persalinan. Trans Info Media: Jakarta.

Maternity., Putri., Yuliyantina 2016. Asuhan Kebidanan Persalinan. Binarupa Aksara Publisher.

Notoadmodjo, S, 2012. Metodologi Penelitian Kesehatan. Jakarta: Rineka Cipta.

Prawirohardjo, 2016. Yayasan Bina Pustaka Sarwono Prawirohardjo. EGC. Jakarta.

Rifani, Ulmi, 2017. Penerapan Konsumsi Telur Ayam Rebus Untuk Percepatan
Penyembuhan Luka Perineum Pada Ibu Nifas Di Bpm Heni Winarti Desa Jatijajar, Ayah, Kebumen. Gombong: Universitas Muhammadiyah.

Riyadi dkk. (2012). Stanndar Operating Procedure Dalam Praktik Klinik Keperawatan Dasar. Pustaka Pelajar : Celeban Timur.

Rukiyah, Ai, Yeyeh. (2015) Asuhan Kebidanan Patologi Kebidanan Edisi Revisi. Jakarta: Trans Infomedia.

Rukiyah dk. (2009). Asuhan Kebidanan Persalinan II. Trans Info Media: Jakarta.

Saleha, Siti. (2009.) Asuhan Kebidanan Pada Masa Nifas. Jakarta: Salemba Medika.

Setyowati. (2014). Perbedaan Efektifitas Pemberian Putih Telur Dan Ikan Gabus Terhadap Penyembuhan Luka Pereneum Ibu Nifas. Griya Husada: Surabaya.

Supiati. (2016). Pengaruh Konsumsi Telur Ayam Ras Rebus Terhadap Peningkatan Kadar Hb Pada Ibu Hamil Trimester II Di Wilayah Kerja Puskesmas Klaten Tengah. Jurnal penelitian. https:/l sanguines. files.wordpress. com/2012/07/.pdf.

Taufan, Nugroho, dr. (2012). Sinopsi Obstetri. EGC: Jakarta.

Walyani Siwi, Elisabet, (2015). Asuhan Kebidanan Masa Nifas dan Menyusui.Pustaka Baru Press: Yogyakarta.

Yuwanta. (2010). Telur Dan Kualitas Telur. Gajah Mada Universitaspress: Yogyakarta. 